\title{
The Effects Of Feminization Of Migration On Family Functions In Tsholotsho District, Zimbabwe
}

\author{
Phillip Thebe \\ Lecturer At Solusi University, \\ Bulawayo. Zimbabwe \\ Gracsious Maviza \\ Research Fellow And Lecturer, \\ Institute Of Development Studies Of The National University Of \\ Science And Technology, Zimbabwe.
}

\begin{abstract}
The paper explores the effects of Feminization of Migration on Family Functions using Tsholotsho District of Zimbabwe as a case in point. It seeks to establish whether there are changes in the manner in which families execute their production, socialization and reproduction functions following the absence of a female member(s) and to understand how these family dynamics resonate with the increase in female migration. The study targeted households with incidents of female migration and employed multistage sampling to choose respondents. Data was gathered using Focus Group Discussions, Questionnaires and Key Informant Interviews. It emerged from the study that due to feminized movements: (i) families have become more of consumption rather than production units; (ii) most families are akin to changing their reproductive systems and; (iii) that the very systems that aid socialization in families have been denigrated. These feminized movements have sometimes dwindled families' abilities of executing their functions and improving their wellbeing. The paper concludes that family functions are neither static nor homogeneous and this partly is due to feminized migration and the life course, which sometimes coerce families to realign their functions so as to deal with various livelihood threats.
\end{abstract}

Key Words: Family Functions, Feminized Migration, Socialization, Reproduction, Family

\section{INTRODUCTION}

The interplay between migration and families has become common place in the development discourse due to the growing importance of migration in projecting family livelihoods globally; thus migrant families have attracted significant academic inquiry and programmatic targeting by development interveners Wahyuni [50]. Various multi-dimensional family functions have been cited in literature, and include biological, economic, and socio-cultural functions among others Social Structure, Murdock [33]. This paper is motivated by the reality of increased participation of females in migration (known as feminisation of migration) spanning from various factors and seeks to unearth how families organise themselves to execute their functions following the absence of a female member. More specifically the paper will confine itself to three family functions namely: (a) Production; (b) Socialisation and (c) Reproduction to explore how these have been affected by feminised movements. Based on a study conducted in Tsholotsho District of Zimbabwe, the paper limits itself to to external female migration which it defines as voluntary movement females (internationally) from Zimbabwe to other countries within Africa and beyond for a period ranging from medium to long term. 


\section{Conceptualising the Family and Family Unit}

The term family is rooted in Latin; 'familia' meaning household and 'famulus' meaning servant [16]. A family in ancient times included the household master 'pater familias', his servants, and his descendants (ibid). Meanwhile, the spouse/wife of the 'pater familias' could be either a part of her husband's family (marriage in manu) or part of her birth family (sine manu) [16]. The concept has been used, viewed and implied ambiguously throughout its duration, and no precise definitions have been ascribed to it due to the differences in the structure and function of families across the world [46, 7]. In the 17th century, new Eurocentric connotations of family surfaced, to mean parents and their children (be they biological or adopted) [33]. This form of family, the nuclear family, provided a good starting point in trying to understand families and was defined by Murdock as:

.... a social group characterised by common residence, economic cooperation and reproduction. It includes adults of both sexes, at least two of whom maintain a socially approved sexual relationship, and one or more children, own or adopted, of the sexually cohabiting adults [33: 1].

Contrary to its criticisms $[40,23]$ this definition is not silent on other forms of family, but expresses Murdock's, belief that all other forms are mere extensions or reductions of this basic elementary form [33]. This paper also concurs with the sentiments of Murdock, however emphasising that families are what societies define them to be, and as such, conceptually fluid, varied and as diverse as societies themselves. A 'Family Unit' will therefore be considered to comprise individuals tied together by blood, marriage or adoption who, at some point, share common residence, but most importantly affect one another on a personal level through experiences, values, support, emotions, and belief systems.

\section{EFFECTS OF MIGRATION ON FAMILY FUNCTIONS}

Family functions are defined as activities and services which the family performs, resulting in maintenance and developmental outcomes in its social and personality structures [13]. Economic functions are determinable through family production, economic cooperation and division of labour; biological functions hinge on both biological reproduction and legalising of sexual relations [13]; Socio-cultural functions are discernable through socialisation; provision of status and care as well as emotional support and companionship [33]. These family functions are impacted upon by migration in different ways depending on who migrates and who remains behind amongst family members. This section discusses a general outline of the effects of migration on family functions.

\section{Production, Economic Cooperation and Division of Labour}

Traditionally, the family was both a production and consumption unit, out of which members fulfilled their economic needs, based on the principle of self-sufficiency and division of labour [33]. Due partly to migration, the family is now restricted to the functions of consumption, protection and maintenance of property, with migrants largely cooperating in productivity through provision of remittances (a production outside of the family) [8].These remittances are used to hire or outsource labour in order to replace the migrants and avoid disruptions to the productive system [ibid]. This way, migration would have engendered new economic functions for the family $[9,51]$.

\section{Reproduction}

The family is an important institution of legitimising reproduction, with males and females playing key roles in procreation and child rearing, for the purposes of family continuity and longevity [4, 41]. Once family members migrate, this biological function is altered, if not 
replaced, as migrants invest more of their attention on economic rather than reproductive pursuits [25]; this threatens family longevity and continuity [4, 41].

\section{Socialisation}

Socialisation is also paramount in family studies, and is generally defined, contrary to Murdock [33]'s and Parsons [40]'s definitions, regardless of age or gender to mean a learning process for family members in the life course [38]. Scholars agree that socialisation aims at ensuring effective interaction, relations and functioning within the family and community at large, based on the objectives of teaching members fundamentals of life, to instil societal aspiration and culture, to transmit basic skills and to ensure that members are capable of fulfilling their social roles [33]. Socialisation roles become futile with the absence of migrants, with children left behind or born abroad, and then sent back home to live with in situ care givers, due to economic commitments of biological 'migrant' parents [19]. Children thus become victims of 'deficit care' as is recorded in most migration literature [14, 32, and 53].

\section{Legitimising of Sexual Relationships}

Migration may impede the family's regulatory functions of sexual relationships when migrants are employed as sex workers, exposing them, and their partners, be they migrated or left behind, to risks of HIV infection $[29,48]$. At times it engenders prostitution, cohabitation, extra-marital affairs, and polygamous marriages, wasteful consumption, increased alcoholism, gambling, deflations of the moral fabric, and re-channelling of family resources to personal activities $[15,31]$. Literature also records domestic violence and divorce (both legally and separation), murder and suicide [18]. Upon their return, their reintegration into families is curtailed as [ibid].

\section{Affection, Emotional Support and Companionship}

Haralambos and Holborn [13] pinpoint that families are 'emotional and supportive networks', which protect members from any distress throughout the life course, and femininity comes in handy in executing this function. A study in Honduras reflected the importance of migrant's continued communication with the left behind family, as a way of exercising this function [42]. Contrary, scholars bemoan that migration benefits cannot be compared to the distress, loneliness and sadness suffered by family members remaining at home $[17,21]$.

\section{Status and Supervision}

The family also provides status for its members, which induces a sense of belonging, respect, and protection [24], while also legalising care, supervision, monitoring, and interaction arrangements with clearly defined rules and expectations, power structures, hierarchies and communication systems [33]. While migration boosts family status, it also changes power structures and patterns of authority with migrants gaining significant authority to act beyond family expectations as in the case of marital choices (cohabitation) [3].

\section{FEMINIZATION OF MIGRATION AND THE FAMILY: AN OVERVIEW}

The interplay between migration and families is critical in unravelling the dynamics of female migration, but also to promote policy making that is cognizant of especially families as they are most affected by migration [50]. The discourse and activism of feminism and its subsequent initiatives, is believed, to have been influential in incorporating explanations of the unique experiences of women and men as migrants [52]. Since then, women have waged campaigns and sought for recognition against patriarchal subjugation and especially active participation in the development discourse [ibid]. This together with challenges spanning from conflicts, weak economies and climate variability among others have seen women being active and noticed in migration [8]. Women now constitute a significant proportion of global, continental, 
regional and intra-country migration flows, and are also primary migrants themselves what is popularly known and summed up as Feminization of Migration [8]. Awumbila et al. [3] ascertains that women are now migrating longer distances and for longer periods of times, a phenomenon once known only to exist among males. Some theorists [20] insinuate that, despite the increase in women's migration stocks, women's supposed autonomy and independence remains questionable. Jolly and Reeves [20] maintain that feminization of migration has both a positive and negative bearing on families, affecting relations, reproductive and productive roles and even livelihood structures inherent in the families. This paper therefore explores the effects of feminized migration on family functions using empirical evidence gathered in Ward 19 of Tsholotsho district.

\section{METHODS}

The methodology used in the research was both qualitative and quantitative, and literature and document review guided the selection of questions in the data gathering instruments. Data was collected through focus group discussions; in-depth interviews; semi structured questionnaires as well as desk research. A sample was chosen from Village 5, which has a total of 250 households. Of the 250 households, the researcher used snowballing, with the help of local authorities, to identify those households with female emigrants, from which household heads were interviewed until a saturation point was reached. The researcher also used purposive sampling to select key informants that were interviewed from various governmental and civil society organisations. For triangulation purposes, the researcher also conducted focus group discussions with men, women, and youths randomly selected in the community. The aim was to gather opinions on how feminized migration affects sending families' multifarious functions.

\section{Demographic Data}

\section{FINDINGS}

The researcher received a 100\% and 89\% response rates from the 30 questionnaires distributed and the 9 key informant interviews targeted respectively. Data received shows that that a majority of the female migrants in the study area are single mothers between the ages of 25 and 34 who otherwise left their children back home as they migrated mostly to South Africa. These were reported to hold ' $O$ ' Level as their highest level of education, which reflects on their blue collar, sometimes part time jobs in destination areas. These females whose migration decision was individual were reported to be legal in South Africa using (i) Zimbabwean documentation, continuously renewing them or (ii) accessed South African documentation upon arrival, sometimes even to the extent of changing their nationality and obtaining fake documentation.

\section{Effects of Feminisation of Migration on Family Functions}

Undeniably, feminisation of migration has significant effects on family functions. This paper confines itself to three family functions (1) production, (2) socialisation and (3) reproduction which are discussed in detail below.

\section{Production}

The results revealed that agricultural production had diminished due to a reduction in labour supplies hinging on female emigration and over-dependence on remittances. It emerged that some of the families in the study area now resorted to buying most of their households' supplies than producing their own. Such families spend less time in and derive decreased incomes from agriculture which is contrary to popular beliefs about rural areas $[12,36]$. Meanwhile, the question of sustainability of livelihoods surfaces in the likelihood of remittances stopping. It emerged from Key Informant Interviews (KIIs) that this consumptive 
and less productive nature of families in the study area, is also a result of poor climate conditions which have seen families being cushioned by state and non-state hand-outs. A few responses highlighted families' efforts to ensure continued agricultural production for instance through labour alternatives in the family or in some instances, through 'Amalima', where invited community members help them in their farming activities, after which the participants are given food and at times treated to brewed traditional beer as a way of thanking them. Common practice however is that families employ helpers who assist in production and are paid, using remittances sent by female emigrants, what is known as 'a function of utilising family labour or migration for production' $[31,51]$. This shows that family production is now influenced by factors outside of the family and that female migration has the ability to redefine and reconceptualise economic functions of the family [8].

It emerged that without hired people to help cover labour gaps, families are left in a dire situation where, tasks are shared among the elderly and children (usually left behind). Consequently, the elderly are restricted by age while children experience glitches of balancing their educational programs and household tasks thus essentially disrupting their focus and performance and shifting from being care recipients to being caregivers. A FGD with females insinuated that poor remittance flows sometimes disrupts household maintenance, creating a 'crisis of expectation' [22] as the family 'left behind' look up to female migrants to use their diaspora 'edge' to cover labour gaps in the family.

\section{Socialisation}

Effects of feminised migration on the socialisation function of the family were also explored. Socialisation is referred to as 'a lifelong process of inheriting and learning norms, customs, values and ideologies of the social group into which they have been born, providing an individual with the skills and habits necessary for them to participate in the society and ensure social and cultural continuity'1. In most societies of the world, upon birth, mothers are the primary care givers to the children [33]. However, in the study area, alternative caregivers (most of the times being grandmothers) assume the role of nurturing and care giving in the absence of migrant mothers. Parrenas [39] and Dreby [11] also echoed similar sentiments. These in situ care givers more often offer window-dressing care as highlighted in a KII with the Deputy Head of Tshabanda Primary School that children sometimes come to school without washing their uniforms, undone homework, uncovered books, uncombed hair, and at times come to school late or when seriously ill. Conclusively, care givers become passive guardians, less concerned with socialising children into well nurtured responsible adults [21, 32 and 47].

Furthermore, mothers' absence was vilified to be the major cause of children's misbehaviour in the community at large, coming in various forms such as: drug abuse, crime, prostitution, early marriages, and adult disrespect, and lingering in school premises after learning hours (although sometimes as an act of dodging household chores awaiting them in their home). In other cases, children were victims of rape (at times unconsciously) or showed feelings of sadness, loneliness, anger, hatred and rejection. These behaviours for Zentgraf and Chinchilla [53: 347] 'create generations in crisis'. A KII revealed a sorrowful incident highlighting the foregoing, where a pupil in grade 7 , had been sexually involved with men since grade 3 .

...so I asked the girl back then when she was in grade 3 if the boy (19 or 20 years old) had used a condom (protection), then she said she did not know, meaning she did not know what a condom was, and perhaps didn't even know what she was doing or even its consequences. I can tell you that by the time such a pupil gets to grade 7 , they are

${ }^{1}$ http://www.yourarticlelibrary.com/sociology/socialisation-the-meaning-features-types-stages-andimportance/8529/ 
already experienced and you can't tell them anything about abstinence. A mother should be there to monitor their children as they grow (KII with Deputy Head, Tshabanda Primary School, Tsholotsho District, 2016).

In a KII with the Headman, it emerged that children sometimes refuse the nurturing and correction from, or feel they are the 'bosses' to the care givers (sometimes young themselves) in the absence of their mothers, denouncing whatever instructions intended for their socialisation. This shows the authoritative, emotional, psychological and biological gap left by mothers' absence, which cannot be filled by any other person $(11,47]$.

Findings also showed that most transnational mothers often preferred to communicate with caregivers and thus relegating children into receptors of only physical needs. Scholars also concur that 'mobile phone parenting' [27], results in an ordeal were migrant parents 'set the agenda' for communication in the global care chain, with children being at the receiving end of the bargain [42]. Kufakurinani et al. [21] in the Zimbabwean case, bemoans lack of communication resources, which dwindles the likelihood of direct communication with children left behind.

According to Dreby [11], mothers oftentimes compensate their absence by spoiling their children materially, hence diverting attention away from vital socialisation fundamentals. A key informant from Tshabanda High School highlighted that learners are destructed from their schooling by the 'goodies' (latest labels in clothes, jewellery and gadgets) they receive. They even wish away other fundamentals of life such as education and elderly discipline all because they envisage following their mothers in destination areas [11, 21 and 53].

In most African societies, the community also plays a significant role in child socialisation [5]. As such, community based disciplinary mechanisms come in handy in this process, through instilling community values to members and punishing those breaking the law (ibid). It emerged that a disciplinary committee in the study area commonly referred to as 'idale', was functional only when parents consented to the discipline. It became difficult for this community arm to execute discipline to children with parents abroad. This affirms the concept of gender that migration can alter patterns of authority even at community level [20].

On the contrary, other responses highlighted traces of good family values and disciplinary standards which have been core in ensuring that children remained with good morals, respectful and obedient even when the parents are away. More so, a FGD with youth revealed that some children are not even enticed by their mothers' emigration. Conclusively, contrary to the Western misnomer of an 'ideal' nuclear family, extended family and foster care arrangements in African societies are effective enough to ensure child socialisation even in the absence of biological parents [2].

\section{Reproduction}

In an endeavour to unearth the effects of women's migration on the reproductive function of the family, two key issues will be explored, namely (i) legitimisation of sexual relations, as well as (ii) biological reproduction in families.

\section{Legitimisation of sexual relations}

Haralambos and Holborn [13] stipulate that the regulation of sexual relations function of the family involves institution of certain rules and regulations that guide the interactions and habitation of its members. Murdock [33] gives examples of forbidden practices such as sexual intercourse during mourning, over the course of religious ceremonies, during pregnancy, 
during menstruation and incest taboo among others. On the other hand acceptable sexual relations are legalised through marriage [10]. What is apparent is that feminised migration can alter these rules and regulations instituted by the family [ibid].

It emerged from the findings that Tsholotsho District has limited cases of female migrants legally married in destination areas; instead, increased incidences of casual and transactional sex, cohabitation or 'umasihlalisane' and intimate friendships are common place; others marry legally albeit in the absence of their families. Maphosa [30] earlier noted that such arrangements emanating from socio-economic challenges in the destination are sometimes not recognised by families remaining behind. Culturally, in most African societies, for a union between a male and a female to be recognised or solemnised as a marriage (customarily), families of both parties engage in lobola ${ }^{2}$ negotiations and other traditions and rituals that culminate into the legitimation and blessing of the relationship [28]. Those who may wish to rectify their errors and solemnise their relationships may make arrangements to involve both families to initiate the processes leading to marriage while already cohabiting with their partners who are usually fellow Zimbabweans with similar traditions and values. Another common occurrence in the study area is that most females tend to return home with children whose fathers are not known to the family. In some cases, the female, her partner and the child will be staying together as a family back in South Africa while in others, they may have separated and the female returning to leave the child with her parents or extended family back home. Similar sentiments were iterated by scholars $[31,45]$. It also emerged that due to the economic hardships within sending families, coupled with the anticipation of the supposed benefits from their daughters 'marriages' in destination areas, [Crisis of Expectation, 21], families have been seen to loosen up and flex their values and traditions to accommodate some of these marital arrangements. This was confirmed in a KII with an official from the MGWCD; and proves that this family function has undergone significant alterations, transformations and adaptations, with migrant's now making decisions that best suit them and not necessarily serving the expectations of their families [33].

\section{Biological Reproduction}

Biological reproduction entails a virtuous system of ensuring family continuity as older generations are replaced by new generations primarily through the process of procreation [10]. Procreation is enshrined in the sexual behaviour of family members regulated through the institution of marriage (Murdock, 1949). Once this reproduction system is disturbed, in this case by feminised migration, families are subject to reduction in size or at worst extinction $[10,31]$. Moreover, most African societies believe in having as many children who are believed will keep their elderly parents and provide for all their needs when they grow [35]. From the study, it emerged that a majority of females were motivated to migrate by the need to fend for their children, especially those without breadwinning spouses, hence child bearing becomes least of their priorities since under such conditions [48, NELM Theory].

Notably, the uptake of contraceptive methods has led to a gradual decline in the number of children born in most families as articulated during some KIIs. A majority of the responses (57\%) indicated that even with children, most female migrants were single, showing that they (mostly impregnated) had procreated outside the legality the family [4, 33]. Moreover, the sojourn mentality that characterise certain feminised movements, result in a lack of

\footnotetext{
${ }^{2}$ A marital practise that involves a male paying in cash or in kind(usually cattle or other livestock) a token of appreciation to his in laws for having brought up or raised his prospective wife, but also as a signal of request for recognition and legitimisation of his relationship with his prospective wife [28]. After payment of lobola a man is considered a part of the in-laws family, and thenceforth can engage in sexual relations with their daughter [ibid].
} 
longitudinal reproduction plans by females, which sees them having non or just a few children, conceiving late or even conceiving then sending the children back home [25,37]. As such, family continuity and longevity $[4,41]$ are slowly being replaced by economic factors in determining reproductive decisions.

\section{CONCLUSION}

Based on the findings presented above, this paper concludes that family functions in contemporary society are neither static nor homogeneous. This is because of the changing life circumstances in families which coerce them to both alter and flex their functioning. Notably, due to the reality of economic hardships and the incapacities inherent in production and reproduction systems, most families have become more of consumption than production units and have changed their biological reproduction systems. The paper also concludes that feminised migration negatively affects the very foundations that aid family socialisation. The paper also concludes that children's development is hindered, since most parents find it difficult to juggle both transnational parenting and economic pursuits in destination areas. These conclusions cement earlier findings by scholars [11, 21, 39 and 53] that mothers' physical presence comes in handy in child socialisation and development. The paper recommends an assessment of transnational parenting and child socialisation/development in order to find ways to find ways to make transnational parenting more effective. It recommends an analysis of alternative care giving in the district to find ways of making it a viable option for migrant parents.

\section{References}

Adams Jr, R. H. (2006). “Remittances, Poverty, and Investment in Guatemala.” In: Ozden, C, and M. Schiff (eds.) International Migration, Remittances and the Brain Drain), Washington D.C. Basingstoke: World Bank - Palgrave Macmillan.

Åkesson, L., C. Jorgen and D. Heike. (2012). "Mobility, Moralities and Motherhood: Navigating the Contingencies of Cape Verdean lives." Journal of Ethnic and Migration Studies, 38 (2): 237-260.

Awumbila, M., J. Kofi Tehe, J. Litchfield, L. Boakye-Yiadom, P. Deshingkar and P. Quartey. (2015). "Are Migrant Households Better off than Non-Migrant Households? Evidence from Ghana." Migration Out of Poverty Working Paper No 28, UK: University of Sussex.

Bilsborrow, R. (1993). "Internal Female Migration and Development: An Overview." In Internal Migration of Women in Developing Countries. Proceedings of the UN Expert Meeting on the Feminization of Internal Migration, Mexico, 22-25 October 1991, UN, New York, 1993, pp1-2.

Boocock, S. S. (2005). Kids in Context: The Sociological Study of Children and Childhoods. New York: Rowman and Littlefield.

Carling, J. (2005). “Gender Dimensions of International Migration.” Global Migration Perspectives No. 35, Geneva: GCIM. Accessed on the $16^{\text {th }}$ of January 2016 from http://www.gcim.org/mm/File/GMP\%pdf

Christensen, H. T ed. (1964). Handbook of Marriage and the Family. Chicago: Rand McNally and Company.

Crush, J and D. Tevera. (2010). “Exiting Zimbabwe”. in Zimbabwe`s Exodus, Crisis, Migration and Survival, edited by Crush, J and D. Tevera. (Eds), Southern African Migration Programme, Cape Town.

Deere, C. D., and A. De Janvry. (1979). "A Conceptual Framework for the Empirical Analysis of Peasant." American Journal of Agricultural Economics, 61(4): 601-611.

Di Renzo, G. J. (1990). Human Social Behaviour: Concepts and Principles of Sociology. USA: Holt, Rinehart and Winston, Inc, 1990.

Dreby, J. (2006). “Honour and Virtue: Mexican Parenting in the Transnational Context." Gender and Society, 32 (56): 222-242.

Feyissa, R. (2007). “The Sub-Saharan African Agriculture: Potential, Challenges and Opportunities”. Paper written for the $1^{\text {st }}$ conference: Can Africa Feed Itself, Oslo, Norway, 6-8 June 2007. 
Haralambos, M. and M. Holborn. (2008). Sociology: Themes and Perspectives (7th ed.). London: Harper Collins, Publishers Limited.

Hernandez, M. G. (2013). "Migrating Alone or Re-Joining the Family? Implications of Migration Strategies and Family Separations for Latino Adolescents." Research in Human Development, 4 (2): 104-118.

Hettige, S. T. (1992). “Three Migration Pockets: A Sociological View Point”, in Labour Migration to the Middle East, edited by Eelans, F et.al.vc (eds.). London: Kegan Paul.

Hill, R and D. A. Hansen. (1960). “The Identification of Conceptual Frameworks Utilized in Family Study.” Marriage and Family Living (Minneapolis, Minn.), 22(1): 299-311.

Hondagneu-Sotelo, P. (1992). “Using Ethnography to Develop Policy for Immigrant Women Domestic Workers.” Paper presented at the Third Women's Policy Research Conference, Institute for Women's Policy Research and American University, Washington D.C., May 14-16.

Immigration and Refugee Board of Canada. (2010). Zimbabwe: Domestic Violence and Sexual Violence: State Protection and Availability of Support Services (2005 - August 2010). Accessed on the $11^{\text {th }}$ of January 2016 from http://www.unchr.org/refworld/docid/4dddf3732.html

IOM. (2014a). The International Organization for Migration in brief, June 2014. Accessed on the $31^{\text {st }}$ of February 2016 from http://www.iom.int/jahia/webdav/site/myjahiasite/shared/shared/mainsite

Jolly, S. and H. Reeves. (2005). “Gender and Migration: Overview Report”. GCIM Workshop on Gender and Migration, March 2005. Geneva: BRIDGE /Institute of Development Studies.

Kufakurinani, U. (2012). "A crisis of Expectation? Narratives on the Impact of Migration on Gender and Family in Zimbabwe, 2000-2011." Department of Economic History, University of Zimbabwe. Zambezia, (1/2).

Kufakurinani, U., D. Pasura and J. McGregor. (2014). “Transnational Parenting and the Emergence of 'Diaspora Orphans' in Zimbabwe" African Diaspora, (7): 114-138.

Lamanna, M. A., and A. Riedman. (2012). Marriages, Families, and Relationships: Making Choices in a Diverse Society (7th ed.). Wadsworth: Cengage Learning, 2012.

Lee, E. (1969). “A Theory of Migration.” in Migration, edited by J. A. Jackson (ed). Cambridge: Cambridge University Press.

Lefko-Everett, K. (2010). “The Voices of Migrant Zimbabwean Women in South Africa.” in Zimbabwe's Exodus: Crisis, Migration, Survival, edited by J. Crush and D. Tevera, eds, SAMP, Cape Town, 2010.

Lopez- Ekra, S., C. Aghazarm, H. Kotter and B. Mollard. (2011). "The Impact of Remittances on Gender Roles and Opportunities for Children in Recipient Families." Research from the International Organisation for Migration, 19 (1): 69-80.

Madianou, M. and D. Miller. (2011). "Mobile Phone Parenting: Reconfiguring Relationships between Filipina Migrant Mothers and their Left-Behind Children." New Media \& Society, 13 (3): 457-470.

Mangena, T. and S. Ndlovu. (2013). "Implications and Complications of Bride Price Payment among the Shona and Ndebele of Zimbabwe." International Journal of Asian Social Science, 3(2): 472-481.

Mansuri, G. (2007). "International Migration, Economic Development and Policy Chapter: Does Work Migration Spur Investment in Origin Communities?" Entrepreneurship, Schooling, and Child Health in Rural Pakistan, page 99140. Washington, DC: World Bank and Palgrave Macmillan.

Maphosa, F. (2007). "Remittances and Development: The Impact of Migration to South Africa on Rural Livelihoods in the Southern Districts of Zimbabwe." Development Southern Africa, 24 (1): 123-136.

Maphosa, F. (2012). "Irregular Migration and Vulnerability to HIV\&AIDS: Some Observations from Zimbabwe." Africa Development 37(2): 119 - 135. Available at the Council for the Development of Social Science Research in Africa, 2012 (ISSN 0850- 907

McDuff, E. (2015). Women's Voices from the Zimbabwean Diaspora: Migration and Change. Department of Society and Environment, Truman State University Kirksville, MO

Murdock, G. P. (1949). Social Structure. New York: Macmillan.

Ncube, G. and G. M. Gomez. (2011). Local Economic Development and Remittances in Rural Zimbabwe: Building on Sand or Solid Ground? The Hague: International Institute of Social Studies (ISS Working Paper, 523).

Ndofirepi, A. P. and A. Shumba. (2014). "Conceptions of "Child" among Traditional Africans: A Philosophical Purview." Journal of Human Ecology, 45(3): 233-242. 
Nelson, V., K. Meadows, T. Cannon, J. Morton and A. Martin. (2009). “Uncertain Predictions, Invisible Impacts, and the Need to Mainstream Gender in Climate Change Adaptations." Gender and Development, 10(2): 51-59.

Nzima, D., V. Duma and P. Moyo. (2016). “Migrant Remittances, Livelihoods and Investment: Evidence from Tsholotsho District in the Matabeleland North Province of Zimbabwe" godina 32, travanj 2016, broj 1: 37-62 Otite, O. and W. Ogionwo. (1979). An introduction to Sociological Studies. Ibadan: Heinemann Educational Books. Parreñas, R. S. (2010). "Transnational Mothering: A Source of Gender Conflicts in the Family." North Carolina Law Review, 7(88): 1825-1856.

Parsons, T. (1959). The Social System. London: Routledge and Kegan Paul.

Sachs, J. (2005). The End of Poverty: Economic Possibilities for our Time. New York: N.Y. Penguin books.

Schmalzbauer, L. (2004). "Families across Borders: Honduran Transnational Families In Pursuit Of Survival". Paper Presented at The Annual Meeting of The American Sociological Association, In San Francisco. Accessed on the $5^{\text {th }}$ of April 2016 from www.allacademic.com/meta/p mla ressearchindex.html

Schmalzbauer, L. (2008). "Family divided: The class formation of Honduran transnational families." Global Networks, 8 (3): 329-346.

Shumba, A. (2010). "The Nature, Extent and Impact of the Brain Drain in Zimbabwe and South Africa." Acta Academica, 24(1): 209-241.

Sørensen, N. N., and M. I. Vammen. (2014). "Who Cares? Transnational Families in Debates on Migration and Development." New Diversities, 16(2): 666-685.

Stark, O. (1991). The Migration of Labour. Blackwell, Cambridge and Oxford.

Tacoli, C. (2002). Changing Rural-Urban Interactions in Sub-Saharan Africa and their Impacts on Livelihoods: A Summary. London: International Institute for Environment and Development.

Tevera, D. and J. Crush. (2010). "The New Brain Drain from Zimbabwe”. Migration Policy Series No. 29, SAMP, Cape Town.

Tischler, H. L. (2011). Introduction to Sociology (10th ed.). Wadsworth: Cen gage Learning.

Wahyuni, E. S. (2000). "The Impact of Migration on Family Structure and Functioning: Case Study in Jawa”. PhD. Thesis, Adelaide University, Australia.

Wood, C. H. (1981). "Structural Changes and Households Strategies: A Conceptual Framework for the Study of Rural Migration." Human Organization, 40 (7): 338-349.

Yang, D. (2011). “Migrant Remittances.” Journal of Economic Perspectives, 25(3):129- 151.

Zentgraf, K. M. and N. S. Chinchilla. (2012). "Transnational Family Separation: A Framework for Analysis.” Journal of Ethnic and Migration Studies, 38 (2):345- 366. 